\title{
Interactions between marine bacteria and red tide organisms in Korean waters
}

\author{
Kyeong Ah Seong ${ }^{1, *}$ and Hae Jin Jeong ${ }^{2}$ \\ ${ }^{1}$ Saemankeum Environmental Research Center, Kunsan National University, Kunsan 573-701, Korea \\ ${ }^{2}$ School of Earth and Environmental Sciences, College of Natural Sciences, Seoul National University, Seoul 151-747, Korea
}

There is increasing interest in the relationships between marine bacteria and red tide organisms. Some bacteria are known to kill red tide organisms, and may be responsible for accelerating the termination of red tides. Thus, certain algicidal bacteria have been proposed for the control of red tides. Meanwhile, many red tide organisms are known to feed on marine bacteria. The roles of marine bacteria and red tide organisms are therefore reversible. In Korean waters, the killing of red tide organisms by algicidal bacteria, and also the feeding of red tide organisms on marine bacteria have been extensively investigated. The findings of such studies may influence the conventional view of red tide dynamics, and also planktonic food webs. Here, we review the species and concentrations of algicidal bacteria that kill red tide organisms in Korean waters, as well as the ingestion rate and grazing impact of red tide organisms on marine bacteria. Furthermore, we offer an insight into the ecological roles of these 2 components in marine planktonic food webs.

Key Words: algicidal bacteria; feeding; food web; graze; harmful algal bloom; red tide; trophic interaction

\section{INTRODUCTION}

Red tides-discoloration of the surface of the sea due to the blooms of plankton-constitute one of the most important environmental issues globally. By altering the balance of food webs and causing large-scale mortalities of fish and shellfish, red tides often lead to considerable losses in the aquaculture and tourist industries (Whyte et al. 2001, Curtiss et al. 2008, Richlen et al. 2010, Jeong and Kang 2013, Park et al. 2013c). Thus, many countries are endeavoring to understand the process of red tides, and thereby predict and control their outbreaks (e.g., Mackey et al. 1996). Red tide dynamics are known to be influenced by diverse physical, chemical, and biological properties (Cole 1982, Doucette et al. 1998, Imai et al. 2001, Han et al. 2010, Tang and Gobler 2010, Jeong et al. 2013a, 2013b, Kang et al. 2013, Kim et al. 2013a, 2013b, Lee et al. 2013,
Park et al. 2013b, Yih et al. 2013, Yoo et al. 2013).

Several investigations have revealed that certain bacteria kill red tide organisms, thereby playing an important role in the decline of red tides (Imai et al. 1993, 2001, Doucette et al. 1998, Salomon and Imai 2006). Thus, the killing of red tide organisms by algicidal bacteria has been extensively studied (Fukami et al. 1992, Mayali and Doucette 2002). Meanwhile, in the last 2 decades, many red tide organisms, including phototrophic dinoflagellates and raphidophytes, have been shown to feed on bacteria (Nygaard and Tobiesen 1993, Seong et al. 2006, Jeong et al. 2010a, 2010b, 2010c, Jeong 2011, Park et al. 2013a). The predator-prey relationships of red tide organisms and bacteria (2 major components of marine environments) are therefore reversible. (c) This is an Open Access article distributed under the terms of the Creative Commons Attribution Non-Commercial License (http://creativecommons.org/licenses/by-nc/3.0/) which permits unrestricted non-commercial use, distribution, and reproduction in any medium, provided the original work is properly cited.
Received September 18, 2013, Accepted November 2, 2013

* Corresponding Author

E-mail: scaway@kunsan.ac.kr

Tel: +82-63-469-4913, Fax: +82-63-469-4911 
In Korea, red tides have led to considerable losses in the aquaculture industries (Park et al. 2013c). Thus, methods to control the outbreak and persistence of red tides, and thereby reduce their economic impacts, are urgently required. Several potential control methods have been suggested or implemented (Jeong et al. 2002, 2003a, 2008, Sengco and Anderson 2004, Park et al. 2013c), including the use of mass-cultured algicidal bacteria.

Here, we review the species and concentrations of algicidal bacteria that kill red tide organisms in Korean waters, as well as the ingestion rates and grazing impact of red tide organisms on bacteria. Furthermore, we examine the ecological significance of the interactions between these 2 components of marine environments.

\section{BACTERIA AS KILLERS OF RED TIDE ORGANISMS IN KOREAN WATERS}

\section{Species of algicidal bacteria isolated from Korean waters}

Many bacteria are known to kill red tide organisms in Korean waters (Table 1). In particular, algicidal bacteria that kill the mixotrophic dinoflagellate Cochlodinium polykrikoides, which causes considerable great losses in the Korean aquaculture industry, have been extensively studied (Jeong et al. 2004, 2008, Park et al. 2013c). Such bacteria include Alteromonas sp. strain A14, Alteromonas sp., Bacillus sp. SY-1, Hahella chejuensis KCTC 2396, Micrococcus sp. LG-5, Micrococcus luteus SY-13, Nautella sp., Pseudomonas sp. LG-2, Pseudoalteromonas sp., Sagittula sp., Thalassobius sp., and Vibrio parahaemolyticus (Table 1). The algicidal components of these bacteria were revealed to be Bacillamide and Prodigiosin (Jeong et al. $2003 b$, 2005). In addition, algicidal activity usually peaked at 15 hours and was subsequently maintained (Park et al. 1998, 1999, Jeong et al. 2003b, Oh et al. 2011).

The bacterium Pseudoalteromonas haloplanktis was shown to lyse the cell wall of another mixotrophic dinoflagellate, Prorocentrum minimum; the algicidal activity was revealed to be caused by the release of $\beta$-glucosidase (Kim et al. 2009a). Furthermore, Pseudomonas sp. LG-2 was shown to kill the mixotrophic dinoflagellate Prorocentrum micans (Table 1 ). In addition, Pseudomonas fluorescens and Kordia algicida OT-1 are known to kill the raphidophyte, Heterosigma akashiwo, while Bacillus sp. is known to kill another raphidophyte, Chattonella marina. Bacillus sp. was also shown to kill the mixotrophic dinoflagellates Akashiwo sanguinea and Scrippsiella trochoidea, and the raphidophytes Fibrocapsa japonica and H. akashiwo (Table 1).

Pseudomonas sp. LG-2 killed Prorocentrum micans, but did not kill Alexandrium tamarense, Akashiwo sanguinea, Cochlodinium polykrikoides (Lee and Park 1998). In addition, Pseudoalteromonas haloplanktis killed Prorocen-

Table 1. Algicidal bacteria and target red tide organisms isolated from the Korean waters, and lowest concentrations of algicidal bacteria required to kill red tide organisms (LCBK)

\begin{tabular}{|c|c|c|c|}
\hline Target red tide organism & Algicidal bacteria & $\begin{array}{c}\text { LCBK } \\
\text { (bacteria cells } \mathrm{mL}^{-1} \text { ) }\end{array}$ & Reference \\
\hline \multirow[t]{8}{*}{ Cochlodinium polykrikoides } & Alteromonas sp. strain A14 & $9.0 \times 10^{5}$ & Lee et al. (2008) \\
\hline & Bacillus sp. SY-1 & & Jeong et al. $(2003 b)$ \\
\hline & Hahella chejuensis КСТС 2396 & & Jeong et al. (2005) \\
\hline & Micrococcus luteus SY-13 & $4.4 \times 10^{4}$ & Kim et al. (2008) \\
\hline & Micrococcus sp. LG-5 & $1.0 \times 10^{4}$ & Jeong et al. (2000a) \\
\hline & & & Byun et al. (2002) \\
\hline & Micrococcus sp. LG-1 & $1.3 \times 10^{6}$ & Park et al. (1998) \\
\hline & Vibrio parahaemolyticus & $8.8 \times 10^{5}$ & Seong and Jeong (2011) \\
\hline \multirow[t]{2}{*}{ Prorocentrum micans } & Micrococcus sp. LG-5 & $1.0 \times 10^{4}$ & Jeong et al. $(2000 b)$ \\
\hline & Pseudomonas sp. LG-2 & $1.3 \times 10^{6}$ & Lee and Park (1998) \\
\hline P. minimum & Pseudoalteromonas haloplanktis & $2.5 \times 10^{4} \mathrm{cfu} \mathrm{mL}^{-1}$ & Kim et al. (2009a) \\
\hline \multirow[t]{3}{*}{ Heterosigma akashiwo } & Kordia algicida OT-1 & & Sohn et al. (2004) \\
\hline & Micrococcus sp. LG5 & $1.0 \times 10^{5}$ & Jeong et al. $(2000 a)$ \\
\hline & Pseudomonas fluorescens & $1.0 \times 10^{5} \mathrm{cfu} \mathrm{mL}^{-1}$ & Kim et al. (2007) \\
\hline Chattonella marina & Bacillus sp. & & Kim et al. $(2009 b)$ \\
\hline Chattonella sp. & Micrococcus luteus SY-13 & & Kim et al. (2008) \\
\hline Eutreptiella gymnastica & Micrococcus sp. LG5 & $1.0 \times 10^{5}$ & Jeong et al. $(2000 b)$ \\
\hline Skeletonema costatum & Pseudoalteromonas sp. A28 & & Lee et al. (2000) \\
\hline
\end{tabular}


trum minimum and $P$. donghaiense, but did not kill $A$. sanguinea, A. tamarense, C. polykrikoides, Gymnodinium catenatum, and Heterosigma akashiwo (Kim et al. 2009a). However, Micrococcus sp. LG-5 killed diverse algae such as C. polykrikoides, H. akashiwo, P. micans, and the euglenophyte Eutreptiella gymnastica (Jeong et al. 2000a, $2000 b$ ). Thus, some algicidal bacteria kill specific species of red tide organisms, while others kill a diverse range of red tide organisms.

On the basis the results of laboratory and field experiments, methods to control red tides using mass-cultured algicidal bacteria have been developed (e.g., Kim et al. 2009a). The efficiency of these methods requires the determination of the minimum concentrations of algicidal bacteria. In addition, the efficacy in mesocosms and natural environments must be evaluated.

\section{Lowest concentrations of algicidal bacteria required to kill red tide organisms isolated from Korean waters}

The lowest concentrations of algicidal bacteria required to kill target red tide organisms (LCBK) differ depending on the species of bacteria and red tide organisms (Table 1). For example, the LCBK of Micrococcus luteus SY-13 on C. polykrikoides was $3.7 \times 10^{3}$ cells $\mathrm{mL}^{-1}$, whereas those of Vibrio parahaemolyticus, Micrococcus sp. LG-1, and Alteromonas sp. Al4 ranged from $0.9 \times 10^{6}$ to $1.3 \times 10^{6}$ cells $\mathrm{mL}^{-1}$ (Table 1). In addition, the LCBKs of Pseudomonas sp. LG-2 and Micrococcus sp. LG-5 on P. micans were $1.3 \times 10^{6}$ and $1.0 \times 10^{6}$ cells $\mathrm{mL}^{-1}$, respectively. Thus, before using the control methods in natural environments, the LCBK must be determined.

\section{Mesocosms testing of algicidal bacteria for killing red tide organisms in Korean waters}

The use of algicidal bacteria to kill red tide organisms has frequently been investigated by means of field mesocosms (Kim et al. 2009a). For example, in mesocosms containing $P$. minimum red tide water, $P$. haloplanktis AFMB-08041 was found to reduce the concentration of P. minimum from $1.5 \times 10^{4}$ to $2.3 \times 10^{3}$ cells $\mathrm{mL}^{-1}$ over 5 days (Kim et al. 2009a). Similarly, the algicidal bacterium Micrococcus sp. LG-1 (when applied at a concentration of $10^{4}$ to $10^{5}$ cells $\mathrm{mL}^{-1}$ ) reduced the concentration of $C$. polykrikoides from $4.8 \times 10^{3}$ to $2.0 \times 10^{2}$ cells $\mathrm{mL}^{-1}$ in Masan Bay (Park et al. 1998). However, before applying the method in large-scale field studies, it is important to investigate possible secondary effects on non-target organisms.

\section{BACTERIA AS PREY FOR RED TIDE ORGANISMS IN KOREAN WATERS}

\section{Type of predator}

Mixotrophic red tide dinoflagellates. Many mixotrophic red tide dinoflagellates isolated from Korean waters are known to feed on bacteria (Table 2). For example, Amphidinium carterae, Alexandrium catenella, A. tamarense,

Table 2. Ingestion rates and carbon acquisition of mixotrophic and heterotrophic predators of marine bacteria

\begin{tabular}{|c|c|c|c|c|c|c|c|}
\hline Species (taxon) & ESD & СРP & $\mathrm{CPB}$ & $I_{\max }$ & AC & Body carbon (\%) & Reference \\
\hline \multicolumn{8}{|l|}{ Mixotrophic algae } \\
\hline Heterocapsa rotundata (MD) & 5.8 & 20 & 0.052 & 12.2 & 15.2 & 76.1 & Seong et al. (2006) \\
\hline Heterosigma akashiwo (RA) & 11.0 & 110 & 0.049 & 11.7 & 13.8 & 12.5 & Seong et al. (2006) \\
\hline Prorocentrum minimum (MD) & 12.1 & 130 & 0.067 & 21.9 & 35.2 & 27.1 & Seong et al. (2006) \\
\hline Heterocapsa triquetra (MD) & 15.1 & 220 & 0.055 & 6.0 & 7.9 & 3.6 & Seong et al. (2006) \\
\hline Cochlodinium polykrikoides (MD) & 25.8 & 930 & 0.035 & 17.4 & 14.6 & 1.6 & Seong et al. (2006) \\
\hline Chattonella ovata (RA) & 40.0 & 2,870 & 0.070 & 24.5 & 41.2 & 1.4 & Seong et al. (2006) \\
\hline \multicolumn{8}{|l|}{ Heterotrophic dinoflagellates } \\
\hline Protoperidinium bipes & 7.8 & 40 & 0.080 & 3.5 & 6.7 & 16.8 & Jeong et al. (2008) \\
\hline Pfiesteria piscicida & 13.5 & 180 & 0.089 & 13.7 & 29.2 & 16.2 & Jeong et al. (2008) \\
\hline Oxyrrhis marina & 15.6 & 270 & 0.066 & 71.3 & 113.7 & 42.1 & Jeong et al. (2008) \\
\hline Gyrodinium cf. guttula & 22.4 & 700 & 0.068 & 23.2 & 37.6 & 5.4 & Jeong et al. (2008) \\
\hline
\end{tabular}

ESD, equivalent spherical diameter; $C P P$, carbon content per predator cell used in each experiment ( $\left.\mathrm{pg} \mathrm{C}_{\mathrm{cell}}{ }^{-1}\right)$; $\mathrm{CPB}$, carbon content per bacterial cell used in each experiment ( $\mathrm{pg} C$ cell $^{-1}$ ); $I_{\max }$, maximum ingestion rate (cells predator ${ }^{-1} \mathrm{~h}^{-1}$ ); AC, acquired amount of carbon by a predator from bacteria per day (pg C predator $\left.{ }^{-1} \mathrm{~d}^{-1}\right)$; \% body carbon, percent of acquired carbon to predator's body carbon (\%); MD, mixotrophic dinoflagellate; $\mathrm{RA}$, raphidophyte. 

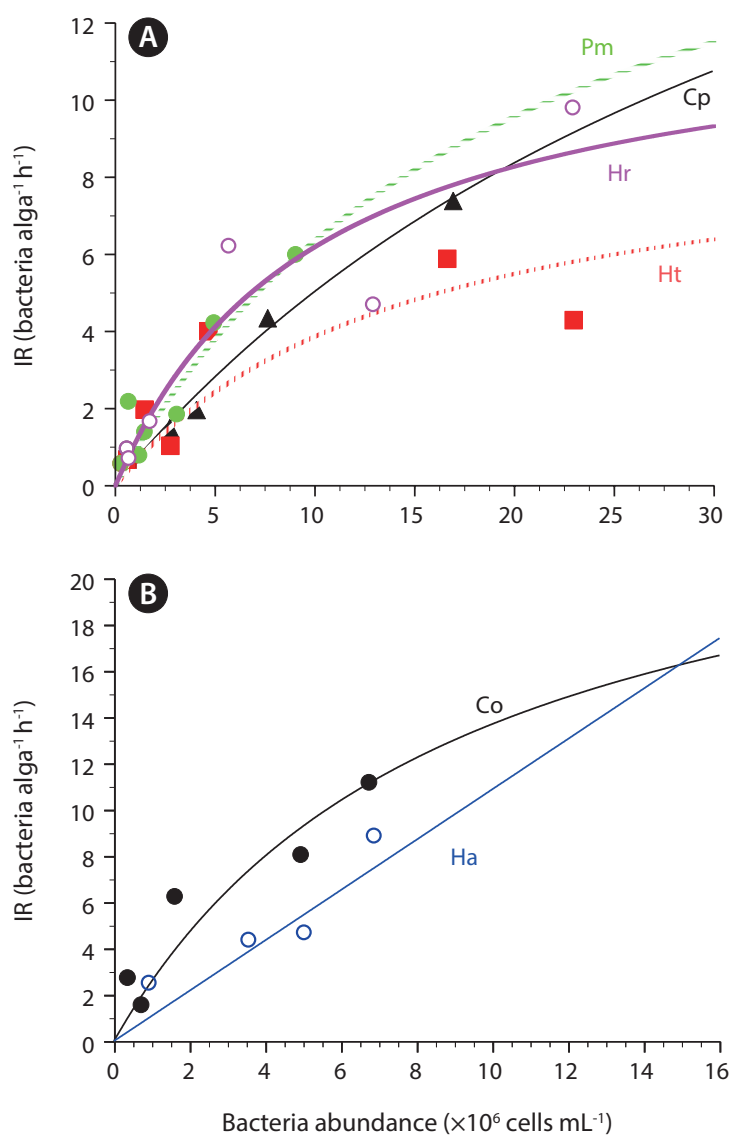

Fig. 1. Ingestion rates (IR; cells alga- ${ }^{-1} h^{-1}$ ) of red tide dinoflagellate (A) and raphidophyte (B) on bacteria as a function of the initial prey concentration. IR values and regression curves were obtained from Seong et al. (2006). Pm, Prorocentrum minimum; Cp, Cochlodinium polykrikoides; $\mathrm{Hr}$, Heterocapsa rotundata; $\mathrm{Ht}$, Heterocapsa triquetra; $\mathrm{Co}$, Chattonella ovate; Ha, Heterosigma akashiwo. Equations: IR $=21.9[\mathrm{x} /$ $\left.\left(23.9 \times 10^{6}+x\right)\right], r^{2}=0.668$ for Pm; IR $=17.4\left[x /\left(26.3 \times 10^{6}+x\right)\right], r^{2}=0.864$ for $\mathrm{Cp} ; \mathrm{IR}=6.0\left[\mathrm{x} /\left(3.2 \times 10^{6}+\mathrm{x}\right)\right], \mathrm{r}^{2}=0.743$ for $\mathrm{Ht}$; IR $=11.2[\mathrm{x} /(9.4 \times$ $\left.\left.10^{6}+x\right)\right], r^{2}=0.709$ for $\mathrm{Hr} ; \mathrm{IR}=24.5\left[\mathrm{x} /\left(7.2 \times 10^{6}+\mathrm{x}\right)\right], \mathrm{r}^{2}=0.703$ for $\mathrm{Co}$; $\mathrm{IR}=11.7\left[\mathrm{x} /\left(4.3 \times 10^{6}+\mathrm{x}\right)\right], \mathrm{r}^{2}=0.771$ for Ha.

Akashiwo sanguinea, Cochlodinium polykrikoides, Gonyaulax polygramma, Gymnodinium aureolum, G. catenatum, G. impudicum, Heterocapsa rotundata, H. triquetra, Lingulodinium polyedrum, Prorocentrum donghaiense, $P$. micans, P. minimum, P. triestinum, and Scrippsiella trochoidea are able to feed on heterotrophic bacteria (Seong et al. 2006, Jeong et al. 2010b). Recently, the zooxanthellae Symbiodinium spp., isolated from Korean waters, were also shown to feed on heterotrophic and autotrophic bacteria (Jeong et al. 2012). Thus, feeding of mixotrophic dinoflagellates on bacteria is common, regardless of genera, size, shape, presence of theca, etc. However, feeding by other mixotrophic red tide dinoflagellates on heterotrophic bacteria has not yet been investigated.

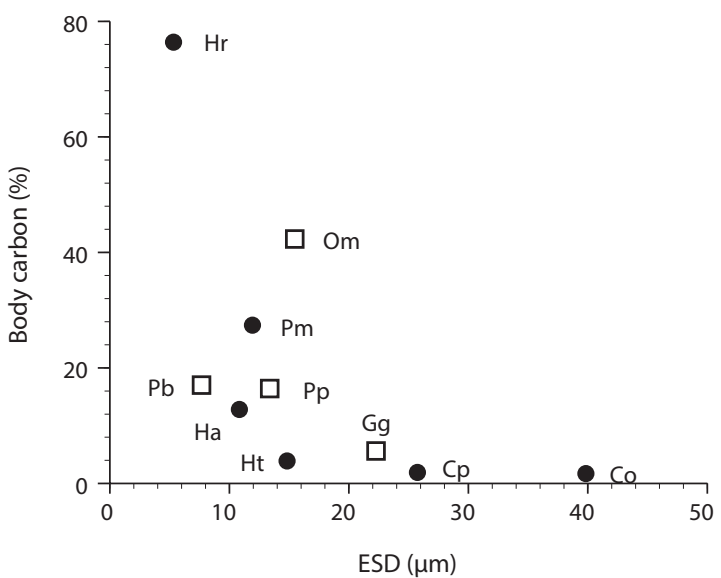

Fig. 2. Amount of carbon acquired by mixotrophic (circles) and heterotrophic (squares) dinoflagellates as a function of algal predator size. Body carbon (\%), percent of acquired carbon from bacteria to predator's body carbon; ESD, equivalent spherical diameter; $\mathrm{Pm}$, Prorocentrum minimum; $\mathrm{Cp}$, Cochlodinium polykrikoides; $\mathrm{Ht}$, Heterocapsa triquetra; $\mathrm{Hr}$, Heterocapsa rotundata; $\mathrm{Ha}$, Heterosigma akashiwo; Co, Chattonella ovata; Om, Oxyrrhis marina; Pp, Pfiesteria piscicida; Pb, Protoperidinium bipes; Gg, Gyrodinium cf. guttula. Data were obtained from Seong et al. (2006) and Jeong et al. (2008).

Ingestion and clearance rates measured in the laboratory. Seong et al. (2006) reported that an increase in the initial bacterial prey concentration to ca. $5 \times 10^{6}$ to $10 \times 10^{6}$ cells $\mathrm{mL}^{-1}$ led to a rapid increase in the ingestion rates by $H$. rotundata, $H$. triquetra, $P$. minimum, and $C$. polykrikoides. At higher prey concentrations, the ingestion rates increased slowly or reached saturation (Fig. 1). The maximum ingestion rates ranged from 6.0 to 21.9 cells alga ${ }^{-1} \mathrm{~h}^{-1}$ (Table 2, Fig. 1). Seong et al. (2006) further reported that the maximum bacterial ingestion rates of 8 red tide algae were not significantly affected by algal size, indicating that the ingestion rates of bacteria may not be determined by the size of red tide algae.

The maximum bacterial clearance rates by red tide algae were $1.0-2.3 \mathrm{~nL}_{\text {alga }}{ }^{-1} \mathrm{~h}^{-1}$ for $H$. rotundata, H. triquetra, P. minimum, and C. polykrikoides (Table 2). These rates are comparable with those of heterotrophic nanoflagellates (HNF, 1.0-4.0 $\mathrm{nL}$ alga-1 $\mathrm{h}^{-1}$ ) (Eccleston-Parry and Leadbeater 1994, Zubkov and Sleigh 1995), but lower than those for ciliates (50-560 $\mathrm{nL}_{\text {alga }}{ }^{-1} \mathrm{~h}^{-1}$ ) (Alonso et al. 2000).

Carbon acquisition from bacterial prey. Seong et al. (2006) reported that the smallest red tide alga, Heterocapsa rotundata, was able to acquire $76 \%$ of its daily body carbon intake from bacteria. The corresponding daily carbon acquisition by P. minimum was $27.1 \%$. These data indicate that bacteria may support positive growth of small red tide dinoflagellates, with the formation of red 
tide patches. Carbon acquisition by $H$. rotundata from bacterial prey exceeds that of the heterotrophic dinoflagellate Oxyrrhis marina, which has the highest value among heterotrophic dinoflagellates (Fig. 2). Seong et al. (2006) further reported that bacteria may not support the growth of the large red tide algae Heterocapsa triquetra and Cochlodinium polykrikoides, which can obtain $<4 \%$ of their daily body carbon intake from bacteria. Calculations of carbon acquisition and maximum volume-specific clearance rates by $H$. triquetra and $C$. polykrikoides indicated that bacteria are not suitable as the sole growth source for these large dinoflagellates, but may be considered as supplementary prey.

Ingestion rates measured in the field. Seong et al. (2006) reported that the mean ingestion rates of natural bacterial populations by mixotrophic red tide dinoflagellates in Korean coastal waters ranged from 1.2 to 20.6 bacteria alga ${ }^{-1} \mathrm{~h}^{-1}$ for $H$. rotundata, H. triquetra, P. minimum, P. triestinum, and C. polykrikoides. In comparison, those of HNFs and ciliates ranged from 0.7 to 39.4 bacteria $\mathrm{HNF}^{-1} \mathrm{~h}^{-1}$ and from 15 to 713 bacteria ciliate ${ }^{-1} \mathrm{~h}^{-1}$, respectively. In contrast, the grazing coefficient of natural bacterial populations by all mixotrophic red tide dinoflagellates (0.012-1.146 $\left.\mathrm{d}^{-1}\right)$ was significantly greater than those by all HNFs (0.008-0.196 $\left.\mathrm{d}^{-1}\right)$ or all ciliates $\left(0.000-0.716 \mathrm{~d}^{-1}\right)$.

H. rotundata / H. triquetra, P. minimum / P. triestinum, and C. polykrikoides were the most effective or the second most effective protistan predators of marine bacteria among the dominant red tide dinoflagellates, HNFs, and ciliate predators (Seong et al. 2006).

\section{Mixotrophic red tide raphidophytes}

The mixotrophic red tide raphidophytes Chattonella, Heterosigma, and Fibrocapsa isolated from Korean waters are known to feed on heterotrophic bacteria (Table 2).

The maximum ingestion rates of Heterosigma akashi$w o$ and Chattonella ovata on heterotrophic bacteria in the predators' cultures are 11.7 and 24.5 cells alga ${ }^{-1} \mathrm{~h}^{-1}$, respectively (Table 2). Seong et al. (2006) reported that $H$. akashiwo was able to acquire $12.5 \%$ of its daily body carbon from bacteria, while C. ovata can obtain $<4 \%$ of their daily body carbon. These data indicate that bacteria may support positive growth of H. akashiwo, but bacteria may be considered as supplementary prey for $C$. ovata.

Seong et al. (2006) reported that the ingestion rate of Heterosigma akashiwo on natural bacteria in Korean waters ranged from 2.7 to 9.0 cells alga ${ }^{-1} \mathrm{~h}^{-1}$ and the grazing coefficient of natural bacterial populations by H. akashiwo ranged from 0.020 to $0.867 \mathrm{~d}^{-1}$. Thus, H. akashiwo may sometimes have considerable grazing impact on natural bacterial populations.

\section{Heterotrophic dinoflagellates}

Jeong et al. (2006) and Yoo et al. (2013) reported that the abundance of the heterotrophic dinoflagellate Pfiesteria piscicida and morphologically similar heterotrophic dinoflagellates (so called Pfiesteria-like dinoflagellates) exceeded 10,000 cells $\mathrm{mL}^{-1}$ (i.e., $>1,000 \mathrm{ng} \mathrm{C} \mathrm{mL}^{-1}$ ) and caused red tides in Korean waters. P. piscicida isolated from Korean waters is known to feed on bacteria (Jeong et al. 2008). The heterotrophic dinoflagellates Oxyrrhis marina and Gyrodinium spp., isolated from Korean waters, were also able to feed on bacteria (Jeong et al. 2008). Jeong et al. (2008) further reported that the maximum bacterial ingestion rates of heterotrophic dinoflagellates were 71.3 cells dinoflagellate ${ }^{-1} \mathrm{~h}^{-1}$ for $O$. marina, 23.2 cells dinoflagellate-1 $\mathrm{h}^{-1}$ for G. cf. guttula, and 13.7 cells dinoflagellate ${ }^{-1} \mathrm{~h}^{-1}$ for P. piscicida. These rates are comparable with those for mixotrophic dinoflagellate (1.2-20.6 cells alga $^{-1} \mathrm{~h}^{-1}$ ), raphidophytes (11.7-24.5 cells alga $\left.{ }^{-1} \mathrm{~h}^{-1}\right)$, HNFs (4-10 cells alga $^{-1} \mathrm{~h}^{-1}$ ) (Eccleston-Parry and Leadbeater 1994, Zubkov and Sleigh 1995), and ciliates (150-380 cells ciliate $^{-1} \mathrm{~h}^{-1}$ ) (Alonso et al. 2000). Therefore, some heterotrophic dinoflagellates may be important predators on marine bacteria (Jeong et al. 2008).

\section{RECIPROCAL PREDATION BETWEEN BACTERIA AND RED TIDE ORGANISMS}

The pathogenic bacterium Vibrio parahaemolyticus is known to be a killer of dinoflagellates, and also to act as prey for red tide dinoflagellates (Seong and Jeong 2011). At $V$. parahaemolyticus concentrations of $>1.5 \times 10^{6}$ cells $\mathrm{mL}^{-1}$, C. polykrikoides is a victim. At V. parahaemolyticus concentration of $1.4 \times 10^{7}$ cells $\mathrm{mL}^{-1}$, G. impudicum is also a victim. At $V$. parahaemolyticus concentrations of $<1.5$ $\times 10^{6}$ cells $\mathrm{mL}^{-1}$, A. carterae, P. minimum, and P. micans are mainly grazers on $V$. parahaemolyticus, whereas at the higher $V$. parahaemolyticus concentration, they may also be victims (Fig. 3). According to these data, Seong and Jeong (2011) proposed that the roles of red tide dinoflagellates and bacteria are reversible, depending on the bacterial concentration. P. micans is able to acquire $9.2 \%$ of its daily body carbon intake (91.8 pg) from V. parahaemolyticus. Thus, $V$. parahaemolyticus may stimulate or partially support the growth of $P$. micans.

On the basis of data derived from studies of bacte- 

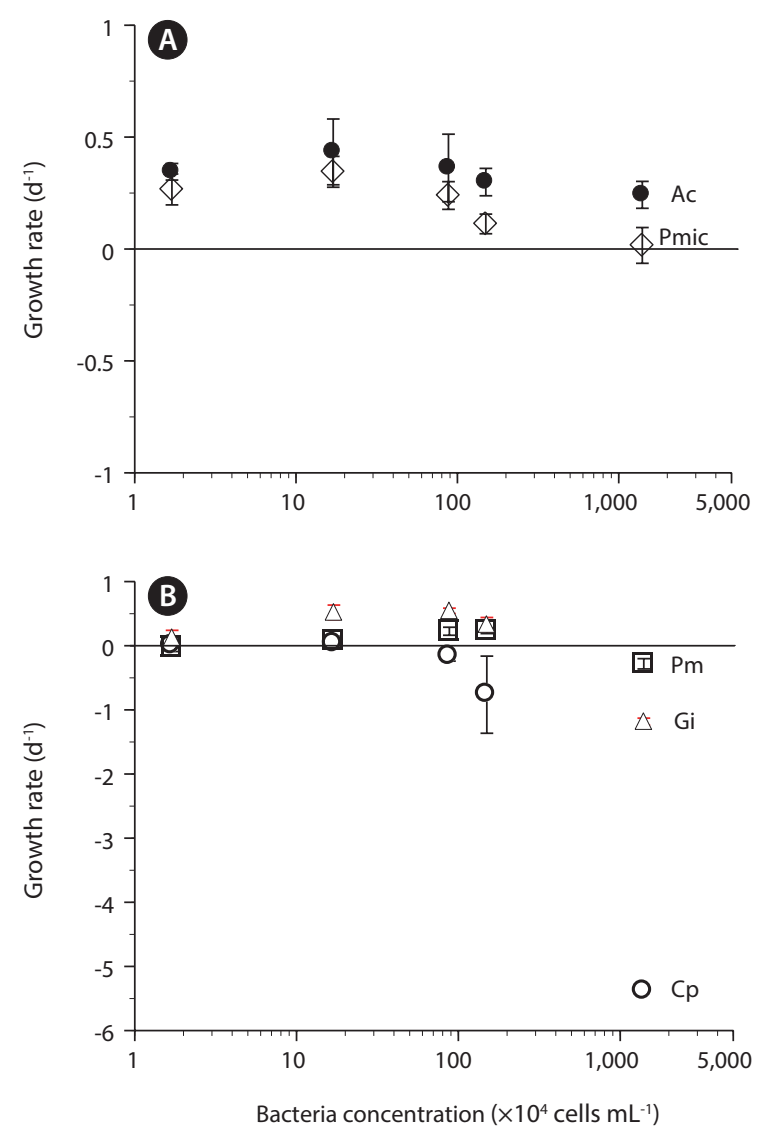

Fig. 3. Growth rate of red tide organism as a function of the abundance of Vibrio parahaemolyticus. (A) Prorocentrum micans (Pmic) and Amphidinium carterae (Ac). (B) Cochlodinium polykrikoides $(\mathrm{Cp})$, Gymnodinium impudicum (Gi), and Prorocentrum minimum (Pm). Figure modified from Seong and Jeong (2011).

rial feeding by red tide organisms, and killing of red tide organisms by algicidal bacteria, a hub of each red tide organism can be drawn (Jeong et al. 2010c). Thus, $C$. polykrikoides can feed on natural bacterial populations and V. parahaemolyticus, but is killed by Bacillus sp., Hahella chejuensis, and Alteromonas sp. (Table 1). Similarly, H. akashiwo can feed on natural bacterial populations, but is killed by Pseudomonas fluorescens, Micrococcus sp. LG5, and Kordia algicida OT-1. Furthermore, P. micans can feed on natural bacterial populations and V. parahaemolyticus, but is killed by Pseudomonas sp. LG2 and Micrococcus sp. LG5. Further studies are required to isolate and identify bacteria during red tides, and to determine whether the bacteria are victims or killers.

\section{ECOLOGICAL SIGNIFICANCE OF THE INTERAC- TIONS BETWEEN BACTERIA AND RED TIDE OR- GANISMS}

Taken together, the results of previous studies on the interactions between heterotrophic bacteria and red tide organisms indicate the following roles of each marine component in the dynamics of the other: 1) bacteria can be killers of red tide organisms; 2) bacteria can clear the body of senescent red tide organisms, by accelerating the decline of a red tide and decomposing the red tide organisms; 3) during some red tides, dominant red tide organisms may be the most effective predators of marine bacteria among protistan predators; and 4) bacteria may be too small to be ingested by filter-feeding copepods, whereas many red tide organisms are ingested by the copepods. Red tide organisms may therefore represent a link between bacteria and some zooplankters, which are unable directly to ingest bacteria.

Thus, bacteria may play diverse roles in red tide dynamics, and may even be critical factors affecting the abundance of red tide organisms in Korean waters.

\section{CONCLUSION}

Marine heterotrophic bacteria and red tide organisms can act as predators and / or prey in Korean waters. Furthermore, their roles are reversible at any time. Thus, these 2 components may co-exist by cycling materials between each other in marine ecosystems. Several methods for controlling red tides using mass-cultured algicidal bacteria have been developed. However, to evaluate the efficiency of these methods in natural environments, intensive field testing is required.

\section{ACKNOWLEDGEMENTS}

We thank Dr. Yeong Du Yoo and Nam Seon Kang for technical supports. This work was supported by the National Research Foundation of Korea Grant funded by the Korea Government/MSICTFP (NRF-C1ABA001-2010-0020702), Mid-career Researcher Program (2012-R1A2A2A01-010987), Ecological Disturbance Program of KIMST, Long-term change of structure and function in marine ecosystems of Korea program of KIMST/ MOF award to HJJ.

\section{REFERENCES}

Alonso, M. C., Rodriguez, V., Rodriguez, J. \& Borrego, J. J. 2000. Role of ciliates, flagellates and bacteriophages on 
the mortality of marine bacteria and on dissolved-DNA concentration in laboratory experimental systems. J. Exp. Mar. Biol. Ecol. 244:239-252.

Byun, H. -G., Jeong, S. -Y., Park, Y. -T., Lee, W. -J. \& Kim, S. -K. 2002. Algicidal activity of substance purified from marine bacteria metabolites against Cochlodinium polykrikoides. J. Fish. Sci. Technol. 5:150-155.

Cole, J. J. 1982. Interactions between bacteria and algae in aquatic ecosystem. Annu. Rev. Ecol. Syst. 13:291-314.

Curtiss, C. C., Langlois, G. W., Busse, L. B., Mazzillo, F. \& Silver, M. W. 2008. The emergence of Cochlodinium along the California Coast (USA). Harmful Algae 7:337-346.

Doucette, G. J., Kodama, M., Franca, S. \& Gallacher, S. 1998. Bacterial interactions with harmful algal bloom species: bloom ecology, toxigenesis, and cytology. In Anderson, D. A., Cembella, A. D. \& Hallegraeff, G. M. (Eds.) Physiological Ecology of Harmful Algal Blooms. Vol. 41. Springer-Verlag, Heidelberg, pp. 619-648.

Eccleston-Parry, J. D. \& Leadbeater, B. S. C. 1994. A comparison of the growth kinetics of six marine heterotrophic nanoflagellates fed with one bacterial species. Mar. Ecol. Prog. Ser. 105:167-177.

Fukami, K., Yuzawa, A., Nishijima, T. \& Hata, Y. 1992. Isolation and properties of a bacterium inhibiting the growth of Gymnodinium nagasakiense. Nippon Suisan Gakkaishi 58:1073-1077.

Han, H. -K., Kim, Y. -M., Lim, S. -J., Hong, S. -S., Jung, S. -G., Cho, H., Lee, W. \& Jin, E. 2010. Enhanced efficiency of TD53, a novel algicidal agent, against the harmful algae via the liposomal delivery system. Int. J. Pharm. 405:137141.

Imai, I., Ishida, Y. \& Hata, Y. 1993. Killing of marine phytoplankton by a gliding bacterium Cytophaga sp. isolated from the coastal sea of Japan. Mar. Biol. 116:527-532.

Imai, I., Sunahara, T., Nishikawa, T., Hori, Y., Kondo, R. \& Hiroishi, S. 2001. Fluctuation of the red tide flagellates Chattonella spp. (Raphidophyceae) and the algicidal bacterium Cytophaga sp., in the Seto Inland Sea, Japan. Mar. Biol. 138:1043-1049.

Jeong, H. J. 2011. Mixotrophy in red-tide algae raphidophytes. J. Eukaryot. Microbiol. 58:215-222.

Jeong, H. J., Ha, J. H., Park, J. Y., Kim, J. H., Kang, N. S., Kim, S., Kim, J. S., Yoo, Y. D. \& Yih, W. H. 2006. Distribution of the heterotrophic dinoflagellate Pfieteria piscicida in Korean waters and its consumption of mixotrophic dinoflagellates, raphidophytes, and fish blood cells. Aquat. Microb. Ecol. 44:263-278.

Jeong, H. J. \& Kang, C. K. 2013. Understanding and managing red tides in Korea. Harmful Algae 30S:S1-S2.

Jeong, H. J., Kim, H. R., Kim, K. I., Kim, K. Y., Park, K. H., Kim,
S. T., Yoo, Y. D., Song, J. Y., Kim, J. S., Seong, K. A., Yih, W. H., Pae, S. J., Lee, C. H., Huh, M. D. \& Lee, S. H. 2002. $\mathrm{NaOCl}$ produced by electrolysis of natural seawater as a potential method to control marine red tide dinoflagellates. Phycologia 41:643-656.

Jeong, H. J., Kim, J. S., Yoo, Y. D., Kim, S. T., Kim, T. H., Park, M. G., Lee, C. H., Seong, K. A., Kang, N. S. \& Shim, J. H. $2003 a$. Feeding by the heterotrophic dinoflagellate $O x$ yrrhis marina on the red-tide raphidophyte Heterosigma akashiwo: a potential biological method to control red tides using mass-cultured grazers. J. Eukaryot. Microbiol. 50:274-282.

Jeong, H. J., Seong, K. A., Kang, N. S., Yoo, Y. D., Nam, S. W., Park, J. Y., Shin, W. G., Glibert, P. M. \& Johns, D. $2010 a$. Feeding by raphidophytes on the cyanobacterium Synechococcus sp. Aquat. Microb. Ecol. 58:181-195.

Jeong, H. J., Seong, K. A., Yoo, Y. D., Kim, T. H., Kang, N. S., Kim, S., Park, J. Y., Kim, J. S., Kim, G. H. \& Song, J. Y. 2008. Feeding and grazing impact by small marine heterotrophic dinoflagellates on heterotrophic bacteria. J. Eukaryot. Microbiol. 55:271-288.

Jeong, H. J., Yoo, Y. D., Kang, N. S., Lim, A. S., Seong, K. A., Lee, S. Y., Lee, M. J., Lee, K. H., Kim, H. S., Shin, W., Nam, S. W., Yih, W. \& Lee, K. 2012. Heterotrophic feeding as a newly identified survival strategy of the dinoflagellate Symbiodinium. Proc. Natl. Acad. Sci. U. S. A. 109:12604-12609.

Jeong, H. J., Yoo, Y. D., Kang, N. S., Rho, J. R., Seong, K. A., Park, J. W., Nam, G. S. \& Yih, W. 2010b. Ecology of Gymnodinium aureolum. I. Feeding in western Korean waters. Aquat. Microb. Ecol. 59:239-255.

Jeong, H. J., Yoo, Y. D., Kim, J. S., Kim, T. H., Kim, J. H., Kang, N. S. \& Yih, W. 2004. Mixotrophy in the phototrophic harmful alga Cochlodinium polykrikoides (Dinophycean): prey species, the effects of prey concentration, and grazing impact. J. Eukaryot. Microbiol. 51:563-569.

Jeong, H. J., Yoo, Y. D., Kim, J. S., Seong, K. A., Kang, N. S. \& Kim, T. H. 2010c. Growth, feeding, and ecological roles of the mixotrophic and heterotrophic dinoflagellates in marine planktonic food webs. Ocean Sci. J. 45:65-91.

Jeong, H. J., Yoo, Y. D., Lee, K. H., Kim, T. H., Seong, K. A., Kang, N. S., Lee, K. H., Lee, S. Y., Kim, J. S., Kim, S. \& Yih, W. H. 2013a. Red tides in Masan Bay, Korea in 2004-2005: I. Daily variations in the abundances of red-tide organisms and environmental factors. Harmful Algae 30S:S75S88.

Jeong, H. J., Yoo, Y. D., Lim, A. S., Kim, T. W., Lee, K. \& Kang, C. K. 2013b. Raphidophyte red tides in Korean waters. Harmful Algae 30S:S41-S52.

Jeong, H., Yim, J. H., Lee, C., Choi, S. -H., Park, Y. K., Yoon, S. H., Hur, C. -G., Kang, H. -Y., Kim, D., Lee, H. H., Park, K. 
H., Park, S. -H., Park, H. -S., Lee, H. K., Oh, T. K. \& Kim, J. F. 2005. Genomic blueprint of Hahella chejuensis, a marine microbe producing an algicidal agent. Nucleic. Acids Res. 33:7066-7073.

Jeong, S. -Y., Ishida, K., Ito, Y., Okada, S. \& Murakami, M. $2003 b$. Bacillamide, a novel algicide from the marine bacterium, Bacillus sp. SY-1, against the harmful dinoflagellate, Cochlodinium polykrikoides. Tetrahedron Lett. 44:8005-8007.

Jeong, S. Y., Park, Y. T., Kim, M. C., Choi, S. C., Seong, H. K., Kim, J. Y., Kim, T. U. \& Lee, W. J. 2000a. Isolation of marine bacteria killing red tide microalgae. IV. Characteristics of algicidal substances, produced from Micrococcus sp. LG-5 and the effects on marine organisms. J. Korean Fish. Soc. 33:339-347.

Jeong, S. Y., Park, Y. T. \& Lee, W. J. 2000b. Isolation of marine bacteria killing red tide microalgae. III. Algicidal effects of marine bacterium, Micrococcus sp. LG-5 against the harmful dinoflagellate, Cochlodinium polykrikoides. J. Korean Fish. Soc. 33:331-338.

Kang, N. S., Lee, K. H., Jeong, H. J., Yoo, Y. D., Seong, K. A., Potvin, É., Hwang, Y. J. \& Yoon, E. Y. 2013. Red tides in Shiwha Bay, western Korea: a huge dike and tidal power plant established in a semi-enclosed embayment system. Harmful Algae 30S:S114-S130.

Kim, J. -D., Kim, B. \& Lee, C. -G. 2007. Alga-lytic activity of Pseudomonas fluorescens against the red tide causing marine alga Heterosigma akashiwo (Raphidophyceae). Biol. Control 41:296-303.

Kim, J. -D., Kim, J. -Y., Park, J. -K. \& Lee, C. -G. 2009a. Selective control of the Prorocentrum minimum harmful algal blooms by a novel algal-lytic bacterium Pseudoalteromonas haloplanktis AFMB-008041. Mar. Biotechnol. 11:463-472.

Kim, J. S., Jeong, H. J., Yoo, Y. D., Kang, N. S., Kim, S. K., Song, J. Y., Lee, M. J., Kim, S. T., Kang, J. H., Seong, K. A. \& Yih, W. H. 2013a. Red tides in Masan Bay, Korea in 2004-2005: III. Daily variation in the abundance of mesozooplankton and their grazing impact on red tide organisms. Harmful Algae 30S:S102-S113.

Kim, M. -J., Jeong, S. -Y. \& Lee, S. -J. 2008. Isolation, identification, and algicidal activity of marine bacteria against Chochlodinium polykrikoides. J. Appl. Phycol. 20:10691078.

Kim, T. W., Lee, K., Lee, C. K., Jeong, H. D., Suh, Y. S., Lim, W. A., Kim, K. Y. \& Jeong, H. J. 2013b. Interannual nutrient dynamics in Korean coastal waters. Harmful Algae 30S:S15-S27.

Kim, Y. S., Lee, D. -S., Jeong, S. -Y., Lee, W. J. \& Lee, M. -S. $2009 \mathrm{~b}$. Isolation and characterization of a marine algi- cidal bacterium against the harmful Raphidophyceae Chattonella marina. J. Microbiol. 47:9-18.

Lee, B. -K., Katano, T., Kitamura, S. -I., Oh, M. -J. \& Han, M. -S. 2008. Monitoring of algicidal bacterim, Alteromonas sp. strain A14 in its application to natural Cochlodinium polykrikoides blooming seawater using fluorescence in situ hybridization. J. Microbiol. 46:274-282.

Lee, C. K., Park, T. G., Park, Y. T. \& Lim, W. A. 2013. Monitoring and trends in harmful algal blooms and red tides in Korean coastal waters, with emphasis on Cochlodinium polykrikoides. Harmful Algae 30S:S3-S14.

Lee, S. -O., Kato, J., Takiguchi, N., Kuroda, A., Ikeda, T., Mitsutani, A. \& Ohtake, H. 2000. Involvement of an extracellular protease in algicidal activity of the marine bacterium Pseudoalteromonas sp. strain A28. Appl. Environ. Microbiol. 66:4334-4339.

Lee, W. -J. \& Park, Y. -T. 1998. Isolation of marine bacteria killing red tide microalgae II. Isolation and algicidal properties of Pseudomonas sp. LG-2 possessing killing activity for dinoflagellate, Prorocentrum micans. J. Korean Fish. Soc. 31:852-858.

Mackey, M. D., Mackey, D. J., Higgins, H. W. \& Wright, S. W. 1996. CHEMTAX: a program for estimating class abundances from chemical markers: application to HPLC measurements of phytoplankton. Mar. Ecol. Prog. Ser. 144:265-283.

Mayali, X. \& Doucette, G. J. 2002. Microbial community interactions and population dynamics of an algicidal bacterium active against Karenia brevis (Dinophyceae). Harmful Algae 1: 277-293.

Nygaard, K. \& Tobiesen, A. 1993. Bacterivory in algae: a survival strategy during nutrient limitation. Limnol. Oceanogr. 38:273-279.

Oh, J. -I., Kim, M. -J., Lee, J. -Y., Ko, I. -J., Kim, W. \& Kim, S. W. 2011. Isolation and characterization of algicidal bacteria from Cochlodinium polykrikoides culture. Biotechnol. Bioprocess Eng. 16:1124-1133.

Park, J., Jeong, H. J., Yoo, Y. D. \&Yoon, E. Y. 2013a. Mixotrophic dinoflagellate red tides in Korean waters: Distribution and ecophysiology. Harmful Algae 30S:S28-S40.

Park, K. -Y., Kim, M. -R. \& Kim, S. -K. 1999. Isolation and characterization of algicidal bacteria KY1. J. Korea Fish. Soc. 32:452-457.

Park, M. G., Kim, S., Shin, E. Y., Yih, W. \& Coats, D. W. $2013 b$. Parasitism of harmful dinoflagellates in Korean coastal waters. Harmful Algae 30S:S62-S74.

Park, T. G., Lim, W. A., Park, Y. T., Lee, C. K. \& Jeong, H. J. $2013 c$. Economic impact, management and mitigation of red tide in Korea. Harmful Algae 30S:S131-S143.

Park, Y. -T., Park, J. -B., Chung, S. -Y., Song, B. -C., Lim, W. 
-A., Kim, C. -H. \& Lee, W. -J. 1998. Isolation of marine bacteria killing red tide microalgae. I. Isolation and algicidal properties of Micrococcus sp. LG-1 possessing killing activity for harmful dinoflagellate, Cochlodinium polykrikoides. J. Korean Fish. Soc. 31:767-773.

Richlen, M. L., Morton, S. L., Jamali, E. A., Rajan, A. \& Anderson, D. M. 2010. The catastrophic 2008-2009 red tide in the Arabian gulf region, with observations on the identification and phylogeny of the fish-killing dinoflagellate Cochlodinium polykrikoides. Harmful Algae 9:163-172.

Salomon, P. S. \& Imai, I. 2006. Pathogens of harmful microalgae. In Edna, G. \& Turner, J. T. (Eds.) Ecology of Harmful Algae. Springer-Verlag, Berlin, pp. 271-282.

Sengco, M. R. \& Anderson, D. M. 2004. Controlling harmful algal blooms through clay flocculation. J. Eukayot. Microbiol. 51:169-172.

Seong, K. A. \& Jeong, H. J. 2011. Interactions between the pathogenic bacterium Vibrio parahaemolyticus and redtide dinoflagellates. Ocean Sci. J. 46:105-115.

Seong, K. A., Jeong, H. J., Kim, S., Kim, G. H. \& Kang, J. H. 2006. Bacterivory by co-occurring red-tide algae, heterotrophic nanoflagellates, and ciliates on marine bacteria. Mar. Ecol. Prog. Ser. 322:85-97.

Sohn, J. H., Lee, J. -H., Yi, H., Chun, J., Bae, K. S., Ahn, T. Y. \& Kim, S. J. 2004. Kordia algicida gen. nov., an algicidal bacterium isolated from red tide. Int. J. Syst. Evol. Microbiol. 54:675-680.

Tang, Y. Z. \& Gobler, C. J. 2010. Allelopathic effects of Cochlodinium polykrikoides isolates and blooms from the estuaries of Long Island, New York, on co-occurring phytoplankton. Mar. Ecol. Prog. Ser. 406:19-31.

Whyte, J. N. C., Haigh, N., Ginther, N. G. \& Keddy, L. J. 2001. First record of blooms of Cochlodinium sp. (Gymnodiniales, Dinophyceae) causing mortality to aquacultured salmon on the west coast of Canada. Phycologia 40:298304.

Yih, W., Kim, H. S., Myung, G., Park, J. W., Yoo, Y. D. \& Jeong, H. J. 2013. The red-tide ciliate Mesodinium rubrum in the Korean coastal waters. Harmful Algae 30S:S53-S61.

Yoo, Y. D., Jeong, H. J., Kim, J. S., Kim, T. H., Kim, J. H., Seong, K. A., Lee, S. H., Kang, N. S., Park, J. W., Park, J., Yoon, E. Y. \& Yih, W. H. 2013. Red tides in Masan Bay, Korea in 2004-2005: II. Daily variation in the abundance of heterotrophic protists and their grazing impact on red-tide organisms. Harmful Algae 30S:S89-S101.

Zubkov, M. V. \& Sleigh, M. A. 1995. Bacterivory by starved marine heterotrophic nanoflagellates of two species which feed differently estimated by uptake of dual radioactive labelled bacteria. FEMS Microbiol. Ecol. 17:57-65. 